\title{
VIRULENCE OF SUNFLOWER BROOMRAPE (Orobanche cumana Wallr.) IN SOME REGIONS OF NORTHERN CAUCASUS
}

Antonova, T.S. , Araslanova, N.M., Guchetl, S.Z., Tchelustnikova, T.A., Ramazanova, S.A., Trembak, E.N.

All Russia Research Institute of Oil Crops by the name of V.S. Pustovoit, (VNIIMK) 350038, Krasnodar, Russia

Received: July 15, 2009 Accepted: November 10, 2009

SUMMARY

After a long period (about 30 years) without broomrape problems in sunflower fields, intensive infestations were observed in some parts districts of Northern Caucasus. Virulence of the pathogen populations from some regions of Northern Caucasus was compared with those of race $F$ from Spain and a mixture of races F, G, H from the European part of Turkey. It was shown that the broomrape populations from Northern Caucasus have heterogeneous structure. The populations Svetlogradskaya, collected in 2005, and Morozovskaya, collected in 2006, were most virulent. The first has the virulence comparable to one from Turkey and it is a mixture of nonvirulent and virulent races for the studied sunflower genotypes. Race $\mathrm{F}$ predominates in the mixture and has a there is an admixture (although insignificant) of more virulent individuals. The population Privolnenskaya from 2003 collection, is a mixture of different races also, but it is less virulent, containing race $\mathrm{E}$ and some insignificant admixture of more virulent individuals (most likely race F).

Key words: sunflower broomrape, Orobanche races, Northern Caucasus, virulence, resistant lines

\section{INTRODUCTION}

The broomrape (Orobanche cumana Wallr.) has a long history of parasitism on sunflower in Russia, longer than one century. During this period, this serious parasite had three times driven the sunflower production to the brink of extinction. The problems were successfully overcome in the former USSR by the development of resistant open pollinated varieties, and strict adherence of long crop rotations (8 years). Broomrape seeds do germinate on the roots of resistant varieties, but they die at the stage of haustorium development. The cultivation of resistant varieties

* Corresponding author: e-mail: antonova-ts@mail.ru 
and hybrids in the period from mid-1970s until recently has practically led to the elimination of parasite's seeds in the fields. It became difficult to find and collect broomrape seeds necessary for sunflower resistance breeding. But the situation changed in recent years. More and more information kept coming from different regions about strong broomrape attacks on sunflowers. Presently we are dealing with a new, the fourth, wave of broomrape infestation on supposedly resistant sunflowers. The situation resembles that that took place in some European countries at the beginning of this century (Melero-Vara et al., 2000; Pérez-Vich et al., 2002; Kaya et al., 2004; Molinero-Ruiz and Melero-Vara, 2005; Fernandez-Escobar et al., 2008; Schindrova, 2006, Pãcureanu-Joita et al., 2008) etc.

The objective of this investigation was to compare the virulence of broomrape seeds collected over several years in different regions of Northern Caucasus against race $\mathrm{F}$ from Spain and the mixture of races $\mathrm{F}, \mathrm{G}$ and $\mathrm{H}$ from Turkey.

\section{MATERIALS AND METHODS}

Broomrape seeds were collected for several years and in different fields in the locations of Krasnodar, Stavropol and Rostov (Figure 1, Table 1) and stored at $18^{\circ} \mathrm{C}$. The virulence of these populations was estimated on the basis of infestation rate exhibited by inbred lines VK 623 and VK 680, which are broomrape-resistant in Russia. The variety VNIIMK 8883 served as control as it had not been selected for broomrape resistance. 1

Table 1: Characteristic of broomrape seeds collected in different fields in the Northern Caucasus region

\begin{tabular}{lcc}
\hline Location of broomrape seeds collection & Year of collection & Sunflower hybrid-host of parasite \\
\hline Viselkovskaya, Krasnodar region & 2001 & Rigasol \\
Kanevskaya, Krasnodar region & 2003 & Signal \\
Svetlogradskaya, Stavropol region & 2005 & PR63 A 90 \\
Kopanskaya, Krasnodar region & 2006 & Rigasol OR \\
Morozovskaya, Rostov region & 2006 & PR63 A 90 \\
\hline
\end{tabular}

Sunflower plants for inoculation tests were grown in climatic chamber (25$27^{\circ} \mathrm{C}$ ), in pots each containing $10 \mathrm{~kg}$ of soil and sand mixed in the proportion $3: 1$, respectively. Broomrape seeds were added to the mixture at the rate of $100 \mathrm{mg} / \mathrm{kg}$ and distributed in the upper third of the pots. Ten sunflower seeds were sown in each pot. The pots were watered when the upper third of the soil mixture became dry. After 35 days, the plants were taken out from the pots, their roots rinsed with water and the number of broomrape tubercles on the roots counted.

For the virulence comparison of broomrape from different countries, sunflower plants of the hybrid P 96, resistant to race F, and variety Peresvet were grown in plastic glasses filled with $0.5 \mathrm{~kg}$ of the soil mixture. Broomrape seeds were added in the same proportion and conditions in the climatic chamber were as described 
above. Sunflower plants were taken out from the soil mixture 35 days after sowing, their roots rinsed with water and broomrape tubercles counted. Traces of wilted broomrape plants on sunflower roots were also calculated by means of a stereoscopic microscope.

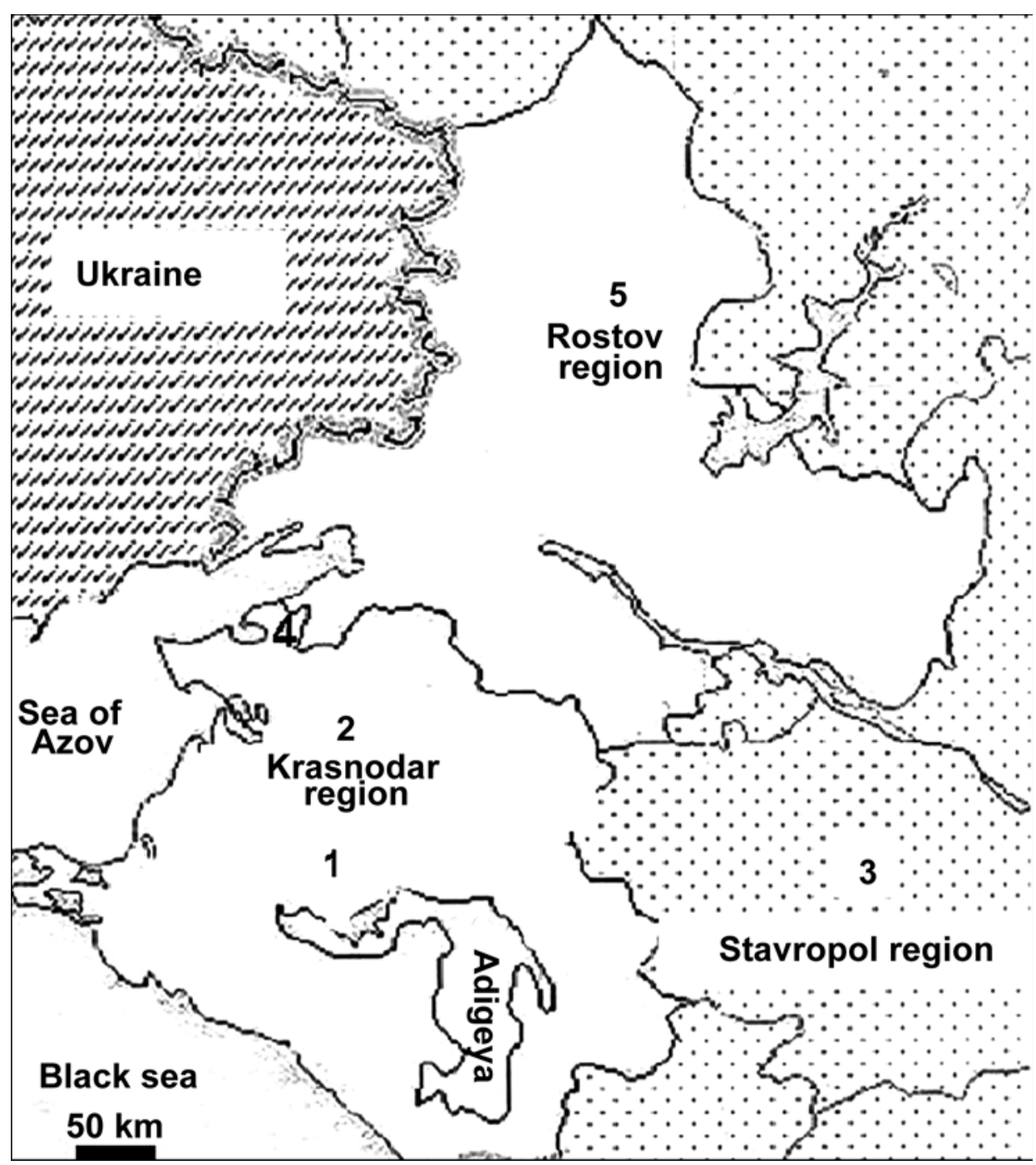

Figure 1: The regions of broomrape seed collection in regions of Northern Caucasus: 1-Viselkouskaya, collected in 2001; 2-Privolnenskaya, 2003;

3-Svetlogradskaya, 2005; 4-Kopanskaya, 2006; 5-Morozovskaya, 2006.

In the 2008 field conditions, experimental plots were inoculated with Privolnenskaya and Svetlogradskaya populations. Broomrape seeds were added to the soil at the rate of $3 \mathrm{~g} / \mathrm{m}^{2}$. Sunflower hybrids which are equally resistant to races A-D but 
differing in resistance to race $\mathrm{E}$ were sown in 4-row plots. At the stage of full ripeness of sunflower heads, broomrape stems were counted. We took into account the percentage of affected plants and the degree of infestation - an average number of parasite stems per single affected plant.

\section{RESULTS AND DISCUSSION}

Inbred lines VK 623 and VK 680 developed at VNIIMK had been resistant to broomrape to the beginning of this century. But data in Table 2 show that now these lines as susceptible. The 5 broomrape populations collected in different years and in different parts of Northern Caucasus were found to exhibit different degrees of virulence. The broomrape seeds collected in 2003 near the village of Privolnaya in Krasnodar region have shown the weakest virulence. The line VK 623 was resistant to this population of the parasite, but $30 \%$ of VK 680 plants had on average 3 broomrape tubercles on their roots. It is an indication that the parasitic population includes individuals capable of overcoming the resistance of this line.2

Table 2: Virulence of sunflower broomrape collected in Krasnodar, Stavropol and Rostov regions in different years in respect to inbred lines VK 623 and VK 680 resistant to race $\mathrm{C}$ in condition of climatic chamber

\begin{tabular}{|c|c|c|c|c|c|c|c|c|c|c|}
\hline \multirow{3}{*}{$\begin{array}{l}\text { Sunflower inbred } \\
\text { lines and variety }\end{array}$} & \multicolumn{10}{|c|}{ Population of broomrape* } \\
\hline & \multicolumn{2}{|c|}{$\begin{array}{c}\text { Viselko- } \\
\text { vskaya, 2001 }\end{array}$} & \multicolumn{2}{|c|}{$\begin{array}{c}\text { Privolnen- } \\
\text { skaya, } 2003\end{array}$} & \multicolumn{2}{|c|}{$\begin{array}{l}\text { Svetlograd- } \\
\text { skaya, } 2005\end{array}$} & \multicolumn{2}{|c|}{$\begin{array}{c}\text { Kopan- } \\
\text { skaya, } 2006\end{array}$} & \multicolumn{2}{|c|}{$\begin{array}{c}\text { Morozovskaya, } \\
2006\end{array}$} \\
\hline & $A^{\star \star}$ & $\mathrm{B}^{\star \star \star}$ & A & $B$ & A & $\mathrm{B}$ & $A$ & $\mathrm{~B}$ & A & $\mathrm{B}$ \\
\hline VK 623 & 48 & 3 & 0 & 0 & 100 & 30 & 20 & 3 & 100 & 22 \\
\hline VK 680 & 80 & 6 & 30 & 3 & 100 & 27 & 12 & 3 & 100 & 40 \\
\hline VNIIMK 8883 control & 100 & 64 & 100 & 42 & 100 & 40 & 100 & 47 & 100 & 73 \\
\hline
\end{tabular}

* Viselkovskaya, Privolnenskaya, Kopanskaya - Krasnodar region;

Svetlogradskaya - Stavropol region; Morozovskaya - Rostov region;

** A - percentage of infested plants;

$\star * \star B$ - infestation degree (a number of broomrape tubercles per plant infested)

Slightly higher virulence was shown by broomrape seeds collected in 2006 near the village of Kopanskaya in Krasnodar region. This population overcame the resistance not only of line VK 680, but also of VK 623 (Table 2). The populations Svetlogradskaya from Stavropol region, collected in 2005, and Morozovskaya from Rostov region, collected in 2006, were most virulent for both lines.

The reaction of all plants of both lines to the broomrape collected near Svetlograd in Stavropol region was comparable with the reaction of the variety VNIIMK 8883 which served as susceptible control in the experiment. A large portion of highly virulent individuals was found in the population Morozovskaya from Rostov region (Table 2).

Seeds of the two populations most different in virulence, Privolnenskaya and Svetlogradskaya, were used for inoculating plots for tests of sunflower hybrids 
characterized as resistant to races A-D, but differing by resistance to race $\mathrm{E}$ (Table 3 ). Their susceptibility was estimated on the basis of broomrape stems number per single plant at the stage of maturity. 3

Table 3: The infestation degree of sunflower hybrids from different countries by broomrape of two Northern Caucasus populations in inoculated fields, 2008

\begin{tabular}{|c|c|c|c|c|c|}
\hline \multirow{3}{*}{ Hybrid } & \multirow{3}{*}{$\begin{array}{c}\text { Resistant to } \\
\text { broomrape } \\
\text { races }\end{array}$} & \multicolumn{4}{|c|}{ Population of broomrape } \\
\hline & & \multicolumn{2}{|c|}{${ }^{\star}$ Privolnenskaya, 2003} & \multicolumn{2}{|c|}{ ^Svetlogradskaya, 2005} \\
\hline & & $\begin{array}{c}\text { number of } \\
\text { infested plants, \% }\end{array}$ & $\begin{array}{c}\text { infestation } \\
\text { degree }^{* *}\end{array}$ & $\begin{array}{c}\text { number of } \\
\text { infested plants, \% }\end{array}$ & $\begin{array}{l}\text { infestation } \\
\text { degree ** }\end{array}$ \\
\hline Rigasol OR & $A-E$ & 40 & 3 & 100 & 8 \\
\hline NK Delphi & $A-E$ & 32 & 3 & 100 & 20 \\
\hline PR 63A90 & $A-E$ & 65 & 7 & 100 & 18 \\
\hline NK Brio & $A-E$ & 20 & 5 & 100 & 12 \\
\hline Arena PR & A-E & 27 & 5 & 50 & 5 \\
\hline Alexandra PR & $A-D$ & 100 & 12 & 100 & 3 \\
\hline NK Armony & $A-D$ & 100 & 7 & 100 & 14 \\
\hline Orasol & $A-D$ & 100 & 13 & 100 & 17 \\
\hline \multicolumn{6}{|c|}{ The control variety } \\
\hline VNIIMK 8883 & Susceptible & 100 & 18 & 100 & 13 \\
\hline
\end{tabular}

* Privolnenskaya -Krasnodar region; Svetlogradskaya -Stavropol Region;

** infestation degree - a number of emerged broomrape stems per plant infested

(it is counted up in a stage of the host full ripeness)

Data in Table 3 show that less than one half of the hybrids plants having resistance to races A - E, were affected by the broomrape population Privolnenskaya and to a low degree. On the other hand, $100 \%$ of the hybrids plants having resistance to only races A - D were intensively affected, 2-3 times more than the former ones. It testifies to the presence of race E individuals in the population Privolnenskaya. Data in Table 3 confirm the observation that the population Svetlogradskaya was considerably more virulent than the population Privolnenskaya. On the basis of its infection rate on the hybrids resistant to races A-E it may supposes that this population (as well as Privolnenskaya) includes races F, G,H declared as highly virulent in some European countries (Schindrova, 2006; Fernandez-Escobar et al., 2008; Pacureanu-Joita et al., 2008). Moreover, race E apparently has been eliminated from this population since infestation numbers of all hybrids (resistant and susceptible to race E) are comparable and the hybrid Alexandra PR has a small degree of infestation, 4 time lower than that achieved by inoculation with Privolnenskaya.

In the other experiment in which the hybrid P 96 and the variety Peresvet were used, the virulence of the populations Svetlogradskaya and Privolnenskaya was compared with those of race F from Spain and races F, G, H from the European part of Turkey (Table 4). This table shows that, with the same infection dose of parasite seeds and identical conditions for sunflower seedlings growth, the number of healthy tubercles of race $\mathrm{F}$ on the roots of the variety Peresvet was 2.5 times less than that of the race mixture from Turkey. The number of healthy tubercles of 

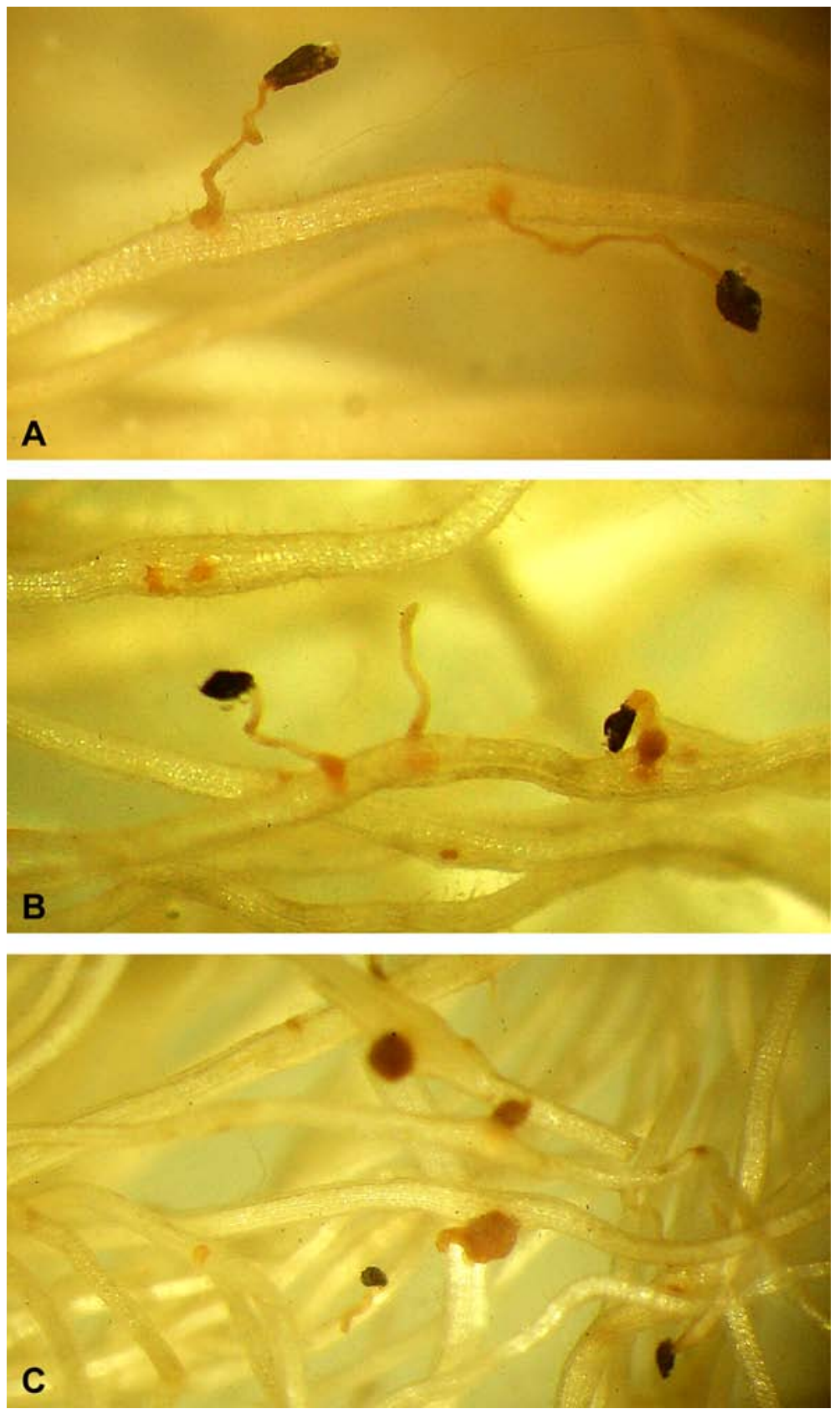

Figure 2: Dead nonvirulent individuals (arrows) of broomrape from population Svetlogradskaya, 2005, on the roots of sunflower variety Peresvet. Parasite died at stages: $A$ - penetration through upper layers of cortical parenchyma; $B$ - contact of haustorial cells with host root vessels; $C$ - developed tubercles. 
broomrape from population Svetlogradskaya is comparable with ones on the mixture of races F, G, H from Turkey. At the same time, the hybrid P 96 has shown complete resistance to race $\mathrm{F}$ and the population Privolnenskaya whereas equally small degrees of infestation, 2 tubercles per plant on average, were registered for the broomrape mixture from Turkey and the population Svetlogradskaya. It is reasonable to conclude that the population Svetlogradskaya is analogous in virulence to the race mixture from Turkey containing race $\mathrm{F}$ with an admixture of the most virulent biotypes. 4

Table 4: The infestation degree* of broomrapes from different countries on the roots of sunflower hybrid P 96 resistant to race F and the variety Peresvet one month after inoculation, 2008

\begin{tabular}{lcccc}
\hline $\begin{array}{l}\text { Variety, } \\
\text { hybrid }\end{array}$ & $\begin{array}{c}\text { Race F, } \\
\text { (Spain) }\end{array}$ & \begin{tabular}{c} 
Mix of races: F, G, H * $\begin{array}{c}\text { *rivolnenskaya, 2003, * } \\
\text { (Turkey) }\end{array}$ \\
\cline { 2 - 6 } (Russia)
\end{tabular} & $\begin{array}{c}\text { Svetlogradskaya, 2005, } \\
\text { Russia) }\end{array}$ \\
\hline Peresvet & 29 & Mean number of healthy broomrape tubercles per plant infested \\
P 96 & 0 & 82 & 15 & 214 \\
\hline
\end{tabular}

* infestation degree - a number of broomrape tubercles per plant infested;

**Privolnenskaya - Krasnodar region, Svetlogradskaya - Stavropol region

Table 3 shows that the population Privolnenskaya included the race E, and Table 4 confirms that some admixtures of race $\mathrm{F}$ are present too.

Microscope observations showed numerous traces of wilted broomrape individuals of the population Svetlogradskaya on the roots of the tested varieties and hybrids. The parasite tended to die at the moment of penetration of haustorial cells into both, cortical parenchyma and the vascular tissue and also at the stage when tubercles have already formed the apical meristem (Figure 2). It demonstrates the heterogeneity of the population races content and the presence of at least races $\mathrm{C}$ and D. It is certain that the individuals of the parasite which die at different stages of penetration into the roots of one and the same host plant belong to diverse races.

\section{CONCLUSION}

The studied broomrape populations from Northern Caucasus were found to have heterogeneous structure. The populations Svetlogradskaya, collected in 2005, and Morozovskaya, collected in 2006, were most virulent. The first has the virulence comparable to that of broomrape mixture from Turkey and it appears to be a mixture of nonvirulent and virulent races for the studied sunflower genotypes. They contain a large portion of race $\mathrm{F}$ and an admixture (although insignificant) of highly virulent individuals. The population Privolnenskaya, collected in 2003 , is also the mixture of different races, but it is less virulent, containing race $\mathrm{E}$ and an insignificant admixture of highly virulent individuals (most likely race $\mathrm{F}$ ). 


\title{
ACKNOWLEDGEMENTS
}

The authors are grateful to Dr J. Melero-Vara from Spain for providing the seeds of the sunflower hybrid $P 96$ and broomrape race F. Also we are very much obliged to Dr N. Beser and Dr Y. Kaya for supplying seeds of the mixture of races $F, G, H$, from Turkey.

\section{REFERENCES}

Melero-Vara, J.M., Dominguez, J., Fernandez-Martinez, J.M., 2000. Update on sunflower broomrape situation in Spain: racial status and sunflower breeding for resistance. Helia 23(33): 45-55.

Pérez-Vich, B., Akhtouch, B., Mu oz-Ruz, J., Fernández-Martínez, J.M. and Jan, C.C., 2002. Inheritance of resistance to a highly virulent race of Orobanche cumana Wallr. in a sunflower line derived from interspecific amphiploids. Helia 25(36): 137-144.

Kaya, Y., Evci, G., Pekcan, V. and Gucer, T., 2004. Determining new broomrape infested areas, resistant lines and hybrids in Trakya region of Turkey. Helia 27: 211-218.

Molinero-Ruiz, M.L. and Melero-Vara, J.M., 2005. Virulence and aggressiveness of sunflower broomrape (Orobanche cumana) populations overcoming the $\mathrm{Or}_{5}$ gene. In: Seiler, G.J., [ed], Proc. $16^{\text {th }}$ Int. Sunflower Conf., Fargo, ND, USA. pp. 165-169

Fernandez-Escobar, J., Rodriguez-Ojeda, M.I., Alonso, L.C., 2008. Distribution and dissemination of sunflower broomrape (Orobanche cumana Wallr.) rase F in Southern Spain. Proc. $17^{\text {th }}$ International Sunflower Conference. Cordoba, Spain, V.1: 231-236.

Shindrova, P., 2006. Broomrape (Orobanche cumana Wallr.) in Bulgaria - distribution and race composition. Helia 29(44): 111-120.

P cureanu-Joita, M., Raranciuc, S., Procopovici, E., Sava, E., Nastase, D., 2008. The impact of the new races of broomrape (Orobanche cumana Wallr.) parasite in sunflower crop in Romania. Proc. $17^{\text {th }}$ International Sunflower Conference. Cordoba, Spain, V. 1: 225230 .

\section{VIRULENCIA DEL JOPO DE GIRASOL (Orobanche cumana Wallr.) EN ALGUNAS REGIONES DEL NORTE CAUCÁSICO}

\author{
RESUMEN
}

Después de un largo período (30 años) con ausencia de jopo en girasol, se observó una fuerte infección de cultivos en algunos distritos del Cáucaso del Norte. Se comparó la virulencia de las poblaciones del patógeno de algunas regiones del norte caucásico con la de raza $\mathrm{F}$ de España y una mezcla de razas: F, G, H provenientes de la Turquía europea. Se demostró que las poblaciones de jopo estudiadas del Cáucaso del Norte tienen una estructura heterogénea. Las poblaciones Svetlogradskaya, colectadas el año 2005, y Morozovskaya, en 2006, son las más virulentas. La primera tiene una virulencia comparable a una de las semillas de Turquía y es una mezcla de razas no virulenta y virulenta para los genotipos de girasol estudiados. Entre ellos, la raza $\mathrm{F}$ tiene un alto contenido y hay una mezcla (todavía insignificante) de los individuos más virulentos. La población Privolnenskaya, colectada en 2003, también es una mezcla de diferentes razas, pero menos virulentas, contiene la raza $\mathrm{E}$ y una mezcla insignificante de los individuos más virulentos (la mayoría como raza $\mathrm{F}$ ). 


\title{
LA VIRULENCE DE I'Orobanche DU TOURNESOL (Orobanche cumana Wallr.) DANS QUELQUES RÉGIONS DU CAUCASE NORDIQUE
}

\author{
RÉSUMÉ
}

Après une longue période (environ 30 ans) sans problèmes rencontrés avec l'Orobanche dans les champs de tournesol, de fortes attaques sur les cultures ont été observées dans certaines zones du Nord du Caucase. Des études ont été menées pour comparer la virulence du pathogène dans ces régions du Caucase nordique, avec celles affectées par la race $\mathrm{F}$ en Espagne, et celles présentant un mélange des races F, G, H dans la partie européenne de la Turquie.

Il a été démontré que les populations d'Orobanche du nord du Caucase avaient une structure hétérogène. Les populations Svetlogradskaya, collection de 2005, et Morozovskaya, 2006, sont les plus virulentes. La première a une virulence comparable à un échantillon de Turquie et est constituée d'un mélange entre races non virulentes et virulentes pour les génotypes des tournesols étudiés.

Parmi ces populations, la race $\mathrm{F}$ est très présente et il $\mathrm{y}$ a en outre un mélange (non significatif) avec les individus les plus virulents. La population Privolnenskaya, de la collection 2003, est le mélange de différentes races également mais elle est moins virulente : elle contient la race $\mathrm{E}$ et un mélange non significatif avec des individus plus virulents (la plupart comme la race $\mathrm{F}$ ). 
